\title{
Socio-economic characteristics of camel (Camelus dromedarius) marketers in Mai'adua livestock market, Katsina State, Nigeria
}

${ }^{1}$ Ghude, M. I., ${ }^{2}$ Maigandi, S. A., ${ }^{3}$ Muhammad, I. R. and ${ }^{4}$ Alkali, H. A.

${ }^{1}$ Veterinary Section, Agric Department, Nassarawa LGA, Kano state

${ }^{2}$ Department of Animal Science, Usmanu Danfodiyo University, Sokoto, Sokoto State

${ }^{3}$ Department of Animal Science, Bayero University, Kano, Kano State

${ }^{4}$ Department of Animal Science, Federal University, Kashere, Gombe State

Corresponding author: elghudemusa@yahoo.com +23408036159450

\section{Abstract}

The study was conducted to assess the socio-economic characteristics of camel marketers at Mai'adua livestock market in Katsina state. Random technique methods were used to select 45 marketers and an interview was used to generate the information. All the correspondents were males and married. Majority (46.67\%) were between the age category of 35-40 years and only $11.11 \%$ were 55 years and above. Majority (75.56\%) attended Qur'anic schools. Niger republic was the major source of the camels as indicated by $68.89 \%$ of the respondents while $17.78 \%$ and $11.11 \%$ indicated Katsina and Jigawa states respectively. Among the animal brought to the market for sales, males out-numbered the females while in the frequency of sales, females out-numbered the males because of variation in prices as indicated by $71.11 \%$ and $55.56 \%$ of the respondents respectively. Majority of the camels purchased were transported to Kano main abattoir for slaughter. There was variation in prices between males and females, stages of growth and development and physiological status. Camel calf (male) had a high price of N70,000 and above while that of female costs N60,000 and above; bull and heifer are sold at a minimum of N90,000 to N95,000 and N70,000 to N75,000 while old camel bull and cow were sold at medium price of between N160,000-N165,000 and N130,000-N135,000 respectively. However, (53.33\%) of the respondents indicated lack of weighing devices as a major constraint and most (46.67\%) indicated inconsistency in pricing among others. A seasonal variation was said to determine the demand. During early rainy season, farmers purchased male camel bulls for farming activities as indicated by the respondents (40.00\%). Lack of awareness on the importance of camel meat also posed a constraint as camel meat was widely consumed (73.33\%) in the area. Cost of camels increased during Eid-El-Kabir as indicated by 44.44\%. The study reported information on marketing, sources, uses and destination of camels respectively.

Key words: Camel Marketers, Prices, Destination, Slaughter, Constraints

\section{Introduction}

One humped camels (Camelus dromedarius) in Nigeria are concentrated in the semi-arid northern part of the country and some few numbers in some parts of central Nigeria used for traction. The introduction of the camels (Camelus dromedarius) into the Northern Nigeria can be linked to the caravan trade links between the Sahara and Sokoto, Katsina, Kano, Bauchi and Borno (Bernus, 1990).
However, DRA (2013) estimated the population of camels in Nigeria as 90,000 in which about $60 \%$ are found in former Sokoto state. The one-humped camel (Camelus dromedarius) plays an important role as a primary source of subsistence agriculture in the arid and semi-arid lands of the tropics (Wilson, 1998). Camels survive in arid and semi-arid areas which are not suitable for crop production and where other livestock species hardly thrive. However, in 
spite of the large number of camels in Nigeria, the productivity of camels is generally low and the camel has been given little attention in research and development. Livestock pastoralism remains a viable food production system in Africa's arid lands (Fratkin and Smith, 1994). The use of the dromedary camel as food and revenue should permit the pastoralists and ranchers in arid Africa to reduce their dependence on higher risk livestock enterprises (Raymond, 1984). Camels are extremely important livestock species in the arid and semi-arid zones in Asia and Africa and contribute significantly to the livelihood of the pastoralists and agro-pastoralists living in the fragile environments (Abbas et al., 2000; Tura et al., 2010). Camels play diverse roles in livelihood of the poor pastoralists, including the building of assets, insurance against unexpected events; have spiritual and social values, traction and movement of goods, food supply and income generation to the pastoralists in the northern part of Nigeria (FAO, 2014) and very recently it plays pronounced a little role in the export revenue of the country in both live animal and transportation (Wilson, 1998 and FAO, 2014).

The increasing human population pressure and declining per capital production of food in Africa precipitated an urgent need to develop previously marginal resources, such as the semi-arid and arid rangelands and to optimize their utilization through appropriate livestock production systems among which camel production is certainly the most suitable (and Schwartz and Dioli, 1992; Getahun and Kassa, 2002; Wardeh, 2004; Mehari et al., 2007). But unfortunately, less attention has been given to camel production improvements for many years when planning national development (FAO, 2014). The potential of camelids is generally underestimated for different reasons (social, economic and religious). Elsewhere, as the camelids are living most of the time in remote areas (desert or high mountains), their accessibility could be difficult. However, according to some convenient surveys, camelids are essential for animal protein supply of human in these marginal areas, contribute to the maintenance of rural activities and economical development and finally facilitate the integration in the global economy (Khanvilkar et al., 2009). Despite the camel's considerable contribution to food security in semi dry and dry zones and its being a major component of the agro-pastoral systems in vast pastoral areas in Africa and Asia, little is known about its production potential and production systems compared to other domestic animals. Researchers and funding agencies have been very reluctant to act on camel research for improvement of their production. Information on camel production potential, marketing systems and consumption of products in northern Nigeria is still very limited. Therefore, the study was conducted at Mai'adua livestock market with the general objective of characterizing camel marketing systems among others.

\section{Materials and methods \\ Studyarea}

The study was conducted at Mai'adua livestock market, Mai'adua Local Government Area, Katsina state, Nigeria. Mai'adua town is one of the 10 districts under Daura Emirate of Katsina state. The state covers an estimated land area of 49,895 square kilometers and shares a boundary with the Republic of Niger to the North; Kano and Jigawa to the east; Zamfara to the west and Kaduna to the south respectively. The population of the 


\section{Ghude, Maigandi, Muhammad and Alkali}

state is over five million during the 2006 National Head Count (NPC, 2006). Katsina state has hot and dry climatic conditions for most of the year in the northern parts of the state. The hottest months are March to May with temperatures ranging from $23^{\circ} \mathrm{C}$ to $42^{\circ} \mathrm{C}$. The annual rainfall varies from $700 \mathrm{~mm}$ to $1000 \mathrm{~mm}$ and rainy season in northern part of the state is usually from June to September KTARDA, (2001).

\section{Sampling procedure}

Mai'adua livestock market is one of the largest livestock markets of cattle and camel in far northern Nigeria beside Maigatari livestock market in Jigawa state. Mai'adua was purposively selected because of its high population of camels. The market day is Sunday of every week.

\section{Data collection}

Data were collected for a period of seven market days from Sunday, June $28^{\text {th }}$-August, $9^{\text {th }} 2015$. Data were collected using structured questionnaire and information obtained from the respondents included: Background information was sex, age, marital status and educational background. Marketing information were source of animals, sex of animals, frequency of sales, price and expected destination after purchase while the Constraints of camel marketing included pricing, season and acceptability

\section{Data analysis}

Data collected were analyzed using simple descriptive statistics of frequency and percentages using statistical package for social sciences (SPSS) version 16.0.

\section{Results and discussion}

Table 1 presents the information of the respondents. All of the correspondents were males. Majority (46.67\%) fall between the ages of 35-40 years. Most (35.55\%) were between the ages of 45-50 years. However, $11.11 \%$ were above the age of 55 years and only $(6.67 \%)$ were between $25-30$ years. From the reports of Ghude et al. (2011), camel marketing is now becoming a practice of the younger generations. All of them were married. It is in the religeo-tradition of the majority of northerners to have more than one wife besides getting marriage at an early age. Majority $(75.56 \%)$ of the respondents attended Qur'anic schools. Most (17.78\%) had primary leaving certificates and $4.44 \%$ and $2.22 \%$ had secondary leaving and tertiary certificates respectively. It is in the tradition of majority of Northerners to send their children to basic Qur'anic schools at early age.

Table 2 shows the marketing information from the study area. Mai'adua is a NigeriaNiger boarder town. As such, majority $(68.89 \%)$ of the camels brought to the market were from Niger republic. Most $(17.78 \%)$ were from the neighboring areas within Katsina state. However, $11.11 \%$ and $2.22 \%$ were from northern Jigawa state and other places respectively. From the results, majority $(71.11 \%)$ of the respondents indicated that majority of the camel population brought to the market for sales were males while $28.89 \%$ indicated female camels. The frequency of sales indicated that majority $(55.56 \%)$ of the respondents were of the opinion that the traders preferred to purchase female camels than the males because of the differences in price. However, most $(44.44 \%)$ purchased male camels. Majority (62.23\%) of the respondents indicated that most of the camels purchased from Mai'adua were transported to Kano main abattoir for slaughtering. Most (28.89\%) of the respondents revealed that camels purchased were transported to Katsina abattoir for slaughter. However, 4.44\% indicated that crop farmers came from Niger state to purchase male camels for 
farming activities and transportation of goods. The remaining $(4.44 \%)$ indicated that camels purchased were transported to Jigawa state for continuous trading; to Kaduna for slaughter; purchased by neighboring traders for fattening among others. This is in agreement with the reports of Ghude et al. (2013) who reported that some local traders purchased camels for fattening while others for farming and utility services.

Table 1: Background information of the respondents from the study area

\begin{tabular}{lll}
\hline Parameters & Frequency & Percentage \\
\hline Sex & 45 & 100 \\
Male & 0 & 0.00 \\
Female & $\mathbf{4 5}$ & $\mathbf{1 0 0 . 0 0}$ \\
Total & & \\
Age & 3 & 6.67 \\
$25-30$ & 21 & 46.67 \\
$35-40$ & 16 & 35.55 \\
$45-50$ & 5 & 11.11 \\
55 and above & $\mathbf{4 5}$ & $\mathbf{1 0 0 . 0 0}$ \\
Total & & \\
Marital status & $\mathbf{0}$ & 0.00 \\
Single & 45 & 100.00 \\
Married & $\mathbf{4 5}$ & $\mathbf{1 0 0 . 0 0}$ \\
Total & & \\
Educational status & 34 & 75.56 \\
Qur'anic education & 0 & 0.00 \\
No formal education & 8 & 17.78 \\
Primary education & 2 & 4.44 \\
Secondary education & 1 & 2.22 \\
Tertiary education & $\mathbf{4 5}$ & $\mathbf{1 0 0 . 0 0}$ \\
Total & &
\end{tabular}

Source: Field survey 2015

Table 3 presented the pricing of camels. Camel pricing varied between stage of development, physiological status, utility services, body conformation, and season of breeding among others. Majority $(73.33 \%)$ of the respondents revealed that the price of camel calf (male) ranged between N60,000-N65,000 while $(15.56 \%)$ and $(11.11 \%)$ of the respondents reported N50,000-N55,000 and N70,000 and above respectively. Camel calf (heifer) had a range of price between N50,000-N55,000 (57.77\%); N40,000-N45,000 (24.45\%) and N60,000 and above $(17.78 \%)$ as revealed by the respondents. Camel bulls are used for breeding, farming activities, transportation among others. Majority $(68.89 \%)$ of the respondents were of the opinion that the price were $\mathrm{N} 110,000$ and above while $(20.00 \%)$ and $(11.11 \%)$ of the respondents reported N90,000-N95,000 and N100,000-N105,000 respectively. Camel heifers are used for breeding and the price normally appreciates in the months of November to March which is the breeding season. This is in harmony with reports Mahmoud, (2010) and Hulsebusch and Kaufman, (2002). However, majority $(64.45 \%)$ indicated the price from N90,000 and above. Most (22.22\%) reported between N80,000 and N85,000 while only $(13.33 \%)$ revealed $\mathrm{N} 70,000$ to $\mathrm{N} 75,000$. Butchers on daily basis prefer the old camel 
Ghude, Maigandi, Muhammad and Alkali

Table 2: Marketing information from the study area

\begin{tabular}{lll}
\hline Parameters & Frequency & Percentage \\
\hline Source of the camels & & \\
Niger Republic & 31 & 68.89 \\
Katsina & 8 & 17.78 \\
Jigawa & 5 & 11.11 \\
Others & 1 & 2.22 \\
Total & $\mathbf{4 5}$ & $\mathbf{1 0 0 . 0 0}$ \\
Sex of the animals & & \\
Males & 32 & 71.11 \\
Females & 13 & 28.89 \\
Total & $\mathbf{4 5}$ & $\mathbf{1 0 0 . 0 0}$ \\
Frequency of sales by sex & & \\
Male & 20 & 44.44 \\
Female & 25 & 55.56 \\
Total & $\mathbf{4 5}$ & $\mathbf{1 0 0 . 0 0}$ \\
Expected destination of camels from Mai'adua market & & \\
Katsina & 13 & 28.89 \\
Kano & 28 & 62.23 \\
Niger & 2 & 4.44 \\
Others & 2 & 4.44 \\
Total & $\mathbf{4 5}$ & $\mathbf{1 0 0 . 0 0}$ \\
\hline
\end{tabular}

Source: Field survey 2015

Table 3: Price of camels at Mai'adua livestock market

\begin{tabular}{|c|c|c|}
\hline Parameters & Frequency & Percentage \\
\hline \multicolumn{3}{|l|}{ Price $(\mathrm{N})$} \\
\hline \multicolumn{3}{|l|}{ Camel calf (male) } \\
\hline $\mathrm{N} 50,000-\mathrm{N} 55,000$ & 7 & 15.56 \\
\hline $\mathrm{N} 60,000-\mathrm{N} 65,000$ & 33 & 73.33 \\
\hline N70,000 and above & 5 & 11.11 \\
\hline Total & 45 & 100.00 \\
\hline \multicolumn{3}{|l|}{ Camel calf (female) } \\
\hline $\mathrm{N} 40,000-\mathrm{N} 45,000$ & 11 & 24.45 \\
\hline $\mathrm{N} 50,000-\mathrm{N} 55,000$ & 26 & 57.77 \\
\hline N60,000 and above & 8 & 17.78 \\
\hline Total & 45 & 100.00 \\
\hline \multicolumn{3}{|l|}{ Camel bull } \\
\hline N90,000 - N95,000 & 9 & 20.00 \\
\hline $\mathrm{N} 100,000-\mathrm{N} 105,000$ & 5 & 11.11 \\
\hline N110,000 and above & 31 & 68.89 \\
\hline Total & 45 & 100.00 \\
\hline \multicolumn{3}{|l|}{ Camel heifer } \\
\hline $\mathrm{N} 70,000-\mathrm{N} 75,000$ & 6 & 13.33 \\
\hline $\mathrm{N} 80,000-\mathrm{N} 85,000$ & 10 & 22.22 \\
\hline N90,000 and above & 29 & 64.45 \\
\hline Total & 45 & 100.00 \\
\hline \multicolumn{3}{|l|}{ Old camel bull } \\
\hline $\mathrm{N} 150,000-\mathrm{N} 155,000$ & 10 & 22.22 \\
\hline $\mathrm{N} 160,000-\mathrm{N} 165,000$ & 23 & 51.11 \\
\hline N170,000 and above & 12 & 26.67 \\
\hline Total & 45 & 100.00 \\
\hline \multicolumn{3}{|l|}{ Old camel cow } \\
\hline $\mathrm{N} 120,000-\mathrm{N} 125,000$ & 7 & 15.56 \\
\hline $\mathrm{N} 130,000-\mathrm{N} 135,000$ & 9 & 20.00 \\
\hline N140,000 and above & 29 & 64.44 \\
\hline Total & 45 & 100.00 \\
\hline
\end{tabular}

Source: Field survey 2015 
bulls with good body conformation for slaughtering. They were of the opinion that the quality and quantity of the carcass and offal were more than that of younger ones in terms of quality of storage and shelf life. From the reports, majority $(51.11 \%)$ of the respondents revealed that the price was between N160,000-N165,000 and most $(26.67 \%)$ and only $(22.22 \%)$ reported N170,000 and above and N150,000N155,000 respectively. The old camel cow had a price range between N140,000 and above; N130,000-N135,000 and N120,000-N125,000 as revealed by $64.44 \%, 20.00 \%$ and $15.56 \%$ respectively. According to the reports of Guliye et al. (2007), camels serve as source of food, cash income, transports means and have significant cultural functions to pastoral communities dominating the semi-arid and arid lands.

Table 4 shows the constraints of camel marketing in the study area. Lack of weighing devices in our livestock markets is a major constraint as indicated by the majority (53.33\%). FAO, (2002) reported that livestock marketing in most of the tropical countries is still practiced in a traditional ways. Physical outlook of an animal is the major point of consideration other than weight among others. Most $(46.67 \%)$ indicated inconsistency in the pricing. An animal purchased on the same market day may drop in price within an interval of hours. They equally indicated that interests from the dealers and middlemen as a serious constraint. Dealers and middlemen determine the price of animals. Seasonal variations were also proved to be one of the constraints in camel marketing. During early rainy season, there was a high demand for matured male camels by crop farmers to be used during rainy season for crop production as revealed by the majority $(40.00 \%)$. In the late rainy season, a demand for camel heifers was high because of the breeding season which is normally between

Table 4: Constraints of camel marketing in the study area

\begin{tabular}{lll}
\hline Parameters & Frequency & Percentage \\
\hline Pricing & 21 & 46.67 \\
Inconsistency & 24 & 53.33 \\
Weighing devices & $\mathbf{4 5}$ & $\mathbf{1 0 0 . 0 0}$ \\
Total & & \\
Season & 18 & 40.00 \\
Early rainy season & 10 & 22.22 \\
Late rainy season & 11 & 24.45 \\
Early dry season & 6 & 13.33 \\
Late dry season & $\mathbf{4 5}$ & $\mathbf{1 0 0 . 0 0}$ \\
Total & & \\
Acceptability & 12 & 26.67 \\
Locally consumed & 33 & 73.33 \\
Widely consumed & $\mathbf{4 5}$ & $\mathbf{1 0 0 . 0 0}$ \\
Total & & \\
Festivities & 11 & 24.45 \\
Eid-El-Fitr & 29 & 64.44 \\
Eid-El-Kabir & 5 & 11.11 \\
Others & $\mathbf{4 5}$ & $\mathbf{1 0 0}$ \\
Total & &
\end{tabular}

Source: Field survey 2015 


\section{Ghude, Maigandi, Muhammad and Alkali}

November to March (Aichoni and Jeblawi, $2007)$ as indicated by $(22.22 \%)$ of the respondents. In the early dry season, most of the females that did not conceive during the breeding season and the older males and females were culled as indicated by $24.45 \%$ of the respondents and it is in agreement with the Mahmud (2010) who reported that camel herders have a strategic ways of culling-out their animals for sales on seasonal basis. However, in the late dry season, $13.33 \%$ revealed that camel herders normally reduce the number of their camels in order to arrest the situation of feed shortage. Karachi et al. (1992) and Neumann (1999) reported that one of the major constraints of camel production in the arid lands is feed especially during the hot dry seasons. Camel meat is not widely accepted or consumed. Cattle are transported from north to the south on daily basis for human consumption while camel consumption is restricted within northern region as revealed by the respondents for $26.27 \%$ and $73.33 \%$ respectively. In the southern part of Nigeria, camel meat is not widely accepted probably because of unavailability, adaptability or lack of awareness Ghude et al. (2012). During EidEl-Kabir, animals, most preferably rams are slaughtered for sacrifice followed camels and cattle in order of preferences. Majority $(64.44 \%)$ of the respondents indicated a high demand during Eid-El-Kabir with $24.45 \%$ and $11.11 \%$ indicating Eid-El-Fitr and other festivities respectively.

\section{Conclusion}

The study shows camels' major source to Mai'adua livestock market was from Ternout, Niger Republic and the major destination was Kano main abattoir for slaughtering. There is a widely acceptance of camel beef consumption in far northern states of Nigeria. Camel pricing resemble that of sheep, goat and cattle. There was no provision of using weighing scales to determine the price using weight. Seasonal variations determine the demand of the camels' categories by various costumers except that butchers purchased both male and females depending on the availability of camels in the market. The study further revealed the inconsistency of price and price variations according to the status of the camels. Little intervention by expertise and government will positively bring about change in the system.

\section{References}

Abbas, B., Al-Qarawi, A. and Al-Hawas, A. 2000. Survey on camel husbandry in Qassim region, Saudi Arabia: Herding strategies, productivity and mortality. Revue D'Livest. Vet. Med. Trop. Countries (French), 53: 293-299.

Aichouni, A. and Jeblawi, R. J. 2007. A study of breeding and reproduction of camels in the Arid and semi-arid lands. Tishreen University. Journal for Study and Scientific Research, Biol. Sci. Series., 29(1): 51-62.

Bernus, E. 1990. Dates, Dromedary and Drought: Diversification in Toureg pastoral system. In: Galaty, J. G. and Johnson, D. L. (editors) The World of Pastoralism. Herding Systems in a Comparative Perspective, Belhaven Press, London, 149-176.

FAO, 2002. Food and Agriculture Organization of the United Nations (FAO), Production Yearbook, Vol. 56. Rome.

FAO, 2014. Food and Agriculture Organization of the United Nations (FAO), contribution of camels to the livelihood of pastoralists. Production yearbook, Rome, Italy.

DRA, 2013. Development Regimes in 
Socio-economic characteristics of camel (Camelus dromedarius) marketers in Mai'adua livestock market, Katsina State

Africa. Agricultural dynamics and food security trends in Nigeria. Research report 2013-ASC-1. Akayinka, A., Ton, D., Dick, F., and Wijnand, K. (eds). Development Regimes in Africa (DRA) Project and ASC-AFCA Collaborative Research Group. The Overseas Development Institute, 203 Blackfrias Road, London. Pp 43.

Fratkin, E. and Smith, K. 1994. Labor, livestock, and land: the organization of pastoral production In" African pastoralist systems: an integrated approach (Book)". Editors Fratkin E, Galvin KA, Roth EA. ISBN 1-55587-322-7. Record Num. 19951808637. Pp 91-112.

Getahun, T. and Kassa, B. 2002. Camel (Camelus dromedarius) husbandry practices in eastern Ethiopia: The case of Jijiga and Shinile zones. $J$. Nomadic Peoples, 6: 158-163.

Ghude, M. I. and Maigandi, S. A. 2011. Socio-economic importance of camel production in Northern Nigeria. In: Adukwu, A. O., Oluwagbemi, T., Aribido, S. O., Daikwo, S. I. and Saliu, O. J. (eds). Proc. of $16^{\text {th }}$ Ann. Conf. of Animal Science Association of Nigeria (ASAN) held at Kogi State University, Ayingba. 12-15 Sept. 2011. Pp 471-473.

Ghude, M. I., Bitto, I. I., Aliyu, I. D. and Umar, M. L. 2012. Acceptability and preferences of camel (Camelus dromedarius) meat consumption in Kano metropolis, Kano state, Nigeria. In: Bitto, I. I.,Kaankuka, F. G. and S. Attah (eds). Proc. of the $37^{\text {th }}$ Ann. Conf. of the Nigerian Society for Animal Production (NSAP) held at Federal University of Agriculture, Makurdi, Benue state, Nigeria.
March, 18-21, 2012. PP 655-656

Ghude, M. I., Bitto, I. I. and Maigandi, S. A. 2013. An assessment of camel fattenning in Maigatari Local Government Area of Jigawa state, Nigeria. In: B. M. Oruwari, J. P. Alawa, U. I. Oji, O. J. Owen and O. S. George (eds). Proc. of the $38^{\text {th }}$ Ann. Conf. of the Nigerian Society for Animal Production (NSAP) held at Rivers State University of Science and Technology (RSUST), Port-Harcourt, Rivers state. March, 17-20. Pp 744-745.

Guliye, A. Y., Noor, I. M., Bebe, B. O. and Koskey, I. S. 2007. Role of camels (Camelus dromedarius) in the traditional lifestyle of Somali pastoralists in northern Kenya. Outlook on Agriculture. 36 (1): 29-34.

Hülsebusch, C. G. and B. A. Kaufmann (Eds.), 2002. Camel Breeds and Breeding in Northern Kenya - An account of local camel breeds of Northern Kenya and camel breeding management of Turkana, Rendille, Gabra, Somali and other tropical pastoralists. Kenya Agricultural Research Institute, Nairobi-Kenya.

Karachi, M. A., Baitachi, D., Ahmad, S., Laman, F. and Dawood, H. G. 1992. The camels: Feeding and watering strategy. The Tropical publishers. 289pp.

Khanvilkar, A. V., Samant, S. R. and Ambore, B. N. 2009. Reproduction in camel, Krantisinh Nana Pati College of veterinary science, Shirval, District Satara. Journal Vet. World, 2(2): 72-73.

KTARDA, 2001. Katsina Agricultural and Rural Development Authority. Meteorological Station Reports, Temperature Records and 
Management Unit No 11:1-3.

Mahmoud, H. A. 2010. Camel (Camelus dromedarius) marketing in the Northern Kenya/Southern Ethiopia Borderlands. FAC Research Update 003. Brighton: Future Agricultures Consortium, University of Sussex.

Mehari, Y., Z. Mekuriawb and G. Gebru, 2007. Potentials of camel production in Babilie and Kebribeyah woredas of the Jijiga Zone, Somali Region, Ethiopia. Livest. Res. Rural Dev., 19: 4-7.

Neumann, A. G. 1999. Survival of Animals in Desert Environment. ILCA Publications, Addis Ababa.

NPC, 2006. National population commission. Year 2006 National head count official result. NPC, HQs, Abuja.

Raymond, H. Morton 1984. Camels for Meat and Milk Production in SubSahara Africa. J. Dairy Sci., Vol. 67. Issue 7, July: 1548-1553.
Schwartz, H. J. and Dioli, M. 1992. Management and Handling of Camels. In: Schwartz, H. J. and Dioli, M. (editors). The one humped camel (Camelus dromedarius) in Eastern Africa: A pictorial guide to diseases, healthcare and management. Verlag Josef, Scientific Books D-6992 Weikersheim, Federal Republic of Germany. Pp 62-154.

Tura, I., Kuria, G., Walaga, H. and Lesuper, J. 2010. Camel Breeding Management among the Somali, Sakuye, Gabbra and Rendille Pastoralists of Northern Kenya. Kenya Agricultural Research Institute, Tropentag, September 14-16, 2010, Zurich, Kenya.

Wardeh, M. F. 2004. The Nutrient Requirement of the Dromedary Camels (Camelus dromedarius). J. Camel Sci. 1:37-45.

Wilson, R. T. 1998. Camels: The Tropical Agriculturalist (CTA), Macmillan Education, London.

Received: $1^{\text {st }}$ October, 2016 Accepted: $23^{\text {rd }}$ February, 2017 